\title{
Comparison of Pharmacological Modulation of APP Metabolism in Primary Chicken Telencephalic Neurons and in a Human Neuroglioma Cell Line
}

\author{
Stefan Czvitkovich • Stephan Duller • Else Mathiesen • Klaus Lorenzoni • \\ Bruno P. Imbimbo • Birgit Hutter-Paier • Manfred Windisch • Robert Wronski
}

Received: 30 April 2010 / Accepted: 18 June 2010 /Published online: 6 July 2010

(C) The Author(s) 2010. This article is published with open access at Springerlink.com

\begin{abstract}
Sequential cleavage of amyloid precursor protein (APP) by $\beta$ - and $\gamma$-secretases and the formation of $A \beta$ peptides are pivotal for Alzheimer's disease. Therefore, a large number of drugs has been developed targeting APP metabolism. However, many pharmacological compounds have been identified in vitro in immortalized APP overexpressing cell lines rather than in primary neurons. Here, we compared the effect of already characterized secretase inhibitors and modulators on $\mathrm{A} \beta$ formation in primary chicken telencephalic neurons and in a human neuroglioma cell line (H4) ectopically expressing human APP with the Swedish double mutation. Primary chicken neurons replicated the effects of a $\beta$-secretase inhibitor ( $\beta$-secretase inhibitor IV), two $\gamma$-secretase inhibitors (DAPM, DAPT), two non-steroidal-anti-inflammatory drugs (sulindac sulfide, $\mathrm{CW}$ ), and of the calpain inhibitor calpeptin. With the exception of the two $\gamma$-secretase inhibitors, all tested compounds were more efficacious in primary chicken telencephalic neurons than in the immortalized $\mathrm{H} 4$ cell line. Moreover, H4 cells failed to reproduce the effect of calpeptin. Hence, primary chicken telencephalic neurons represent a suitable cell culture model for testing drugs interfering with APP processing and are overall more
\end{abstract}

\footnotetext{
S. Czvitkovich · S. Duller · E. Mathiesen $\cdot$ K. Lorenzoni ·

B. Hutter-Paier $\cdot$ M. Windisch $\cdot$ R. Wronski $(\bowtie)$

JSW Lifesciences $\mathrm{GmbH}$,

Parkring 12,

8074 Grambach, Austria

e-mail: rwronski@jsw-lifesciences.com

B. P. Imbimbo

Research and Development, Chiesi-Farmaceutici S.p.A.,

Via Palermo, 26/A,

43100 Parma, Italy
}

sensitive to pharmacological interference than immortalized H4 cells ectopically expressing mutant human APP.

Keywords Alzheimer's disease - A $\beta$ secretion . Culture model $\cdot$ Secretase $\cdot$ Drug testing

\section{Introduction}

Alzheimer's disease (AD) is the most abundant age-related form of dementia. Insoluble amyloid plaques consisting of fibrillar A 342 aggregates are one of the hallmarks of Alzheimer's pathology (Hardy and Selkoe 2002).

$\mathrm{A} \beta$ peptides are generated by $\beta$ - and $\gamma$-secretasemediated cleavage of the amyloid precursor protein (APP), whereas $\alpha$-secretase activity produces only nonamyloidogenic APP fragments and prevents $A \beta$ production (Haass 2004). The $\mathrm{N}$-terminus of the $A \beta$ domain is cleaved by $\beta$-secretase (BACE-1), a step which is essential for the formation of all $A \beta$ peptides including $\mathrm{A} \beta 38, \mathrm{~A} \beta 40$, and $\mathrm{A} \beta 42$ (Cole and Vassar 2008). The $\gamma$-secretase is a protein complex consisting of four subunits, presenilin 1 (PS1) or PS2, APH-1a or APH-1b, PEN-2, and nicastrin, and cuts APP at the intramembranous $C$-terminal end of the $A \beta$ domain (Wolfe 2006). $\mathrm{A} \beta 42$ has the biophysical property to aggregate fast and to form soluble oligomers as well as fibrillar structures, in contrast to $A \beta 40$ and other $A \beta$ peptides (Dahlgren et al. 2002; Walsh and Selkoe 2007). Indeed, soluble $A \beta 42$ oligomers were identified as major pathological source causing neuronal toxicity and cognitive impairment (Haass and Selkoe 2007). In humans, $A \beta 42$ levels are elevated in the cerebral cortex in both sporadic and familiar forms of AD. Mutations either directly in the APP gene, such as the Swedish double mutation at K595N/M596L in human 
APP (Citron et al. 1992; Mullan 1992; Mullan et al. 1992; Citron et al. 1995) or in presenilin genes (De Strooper 2007) elevate total $A \beta 42$ content by increasing $\beta$ - or $\gamma$-secretase-mediated APP cleavage. Thus, A $\beta 42$ formation plays a pivotal role in $\mathrm{AD}$.

In recent years, numerous pharmacological substances have been developed that either inhibit or modulate $\beta$ - and $\gamma$-secretase activity to reduce $A \beta$ production (Ghosh et al. 2008; Imbimbo 2008; Wolfe 2008; Silvestri 2009). However, many in vitro screens aiming to identify substances that alter APP metabolism have been performed in neuronal or non-neuronal cell lines highly overexpressing human wildtype or mutant APP. In contrast to immortalized cell lines, primary neurons produce endogenous levels of APP, undergo differentiation, and form functional synapses and thus exhibit a more physiological system for drug testing.

Primary chicken neurons fulfill the criteria that are required for analyzing APP processing. First, chicken embryos express the long APP751 and APP695 variants during development, which share $93 \%$ sequence identity with human APP (Carrodeguas et al. 2005; Sarasa and Pesini 2009). The human and chick $A \beta 42$ sequences are identical in contrast to rodent $A \beta$ domains, which differ in several amino acids from the human sequence. In addition, chick embryos express the essential enzyme machinery required for both amyloidogenic and non-amyloidogenic processing of APP including $\alpha-, \beta$-, and $\gamma$-secretases (Carrodeguas et al. 2005; Sarasa and Pesini 2009). Indeed, primary cultures of chicken telencephalic neurons secrete detectable levels of $A \beta 1-38, A \beta 1-40, A \beta 1-42$, and soluble APP into their cell supernatant (Esselmann et al. 2004; Leuchtenberger et al. 2009).

In this study, we examined primary chicken telencephalic neurons and a human neuroglioma cell line overexpressing human APP695 with the Swedish double mutation as cell culture models for testing compounds that interfere with APP processing. Therefore, substances previously described to inhibit or modulate APP cleavage were administered, and effects on $\mathrm{A} \beta 38, \mathrm{~A} \beta 40$, and $\mathrm{A} \beta 42$ formation were evaluated.

\section{Material and Methods}

Materials

The following compounds were included in the study: $\mathrm{CW}$ (3,5-bis(4-nitrophenoxy)benzoic acid), DAPM ( $N$ ( $N$-3,5-difluorophenacetyl)- $L$-alanyl- $S$-phenylglycine methyl ester), DAPT ( $N$-[N-(3,5-difluorophenacetyl- $L$ alanyl)]-S-phenylglycine $t$-butyl ester), calpeptin (benzyloxycarbonylleucyl-norleucinal), sulindac sulfide
((Z)-5-fluoro-2-methyl-1-[p-(methylthio)benzylidene $]$ indene-3-acetic acid), and $\beta$-secretase inhibitor IV (all Calbiochem). All compounds were dissolved in dimethyl sulfoxide. The amount of vehicle was kept constant for all concentrations of a respective compound.

For primary chicken telencephalic cultures, Nu Serum was purchased from Becton Dickinson (BD). All other cell medium components, unless indicated, were purchased from Lonza.

Culture of Primary Embryonic Chicken Telencephalic Neurons

Preparation of chicken telencephalic neurons was performed according to Pettmann et al. 1979 with modifications. Embryonic day 8 (E8) embryos from fertilized Lohman Brown hybrid chicken eggs were isolated, and telencephalic neurons were mechanically dissociated using a sterile nylon sieve with pore size $100 \mu \mathrm{M}$ (BD Falcon). Neurons were maintained in Dulbecco's Modified Eagles Medium containing $4.5 \mathrm{~g}$ glucose $/ 1,5 \% \mathrm{Nu}$ Serum, $0.01 \%$ gentamicin, and $2 \mathrm{mM}$ L-glutamine.

For the $\mathrm{A} \beta$ secretion assay, chicken neurons were plated on poly-D-lysine pre-coated 24-well plates (BD Biocoat) at a cell density of $1.8 \times 10^{6}$ neurons per 24 well. After $48 \mathrm{~h}$, culture medium was exchanged, and neurons were incubated for $24 \mathrm{~h}$ with different concentrations of compounds in a total volume of $300 \mu \mathrm{l}$ culture medium. For the MTT viability assay, neurons were plated on poly-D-lysine precoated 96-well plates (BD Biocoat) at a cell density of $3 \times$ $10^{5}$ neurons per 96 well in a total volume of $160 \mu$ l culture medium.

\section{Culture of H4 Cells Ectopically Expressing Human $\mathrm{APP}_{\mathrm{K} 595 \mathrm{~N} / \mathrm{M} 596 \mathrm{~L}}$}

A human neuroglioma $\mathrm{H} 4$ cell line stably transfected with the pAG3 vector containing human APP695 with the Swedish double mutation K595N/M596L was used as cell line model (Haugabook et al. 2001). The pAG3 vector is a modified pcDNA3 plasmid and contains the hygromycin-B resistance cassette with the transgene under the control of a fused $\mathrm{CMV}$ and chicken $\beta$-actin promoter. $\mathrm{H} 4$ cells were plated on 96-well plates (BD) at a cell density of $1 \times 10^{4}$ cells per 96 well in $160 \mu$ OptiMEM (Invitrogen) containing $10 \%$ fetal bovine serum, $1 \%$ penicillin/streptomycin, $200 \mu \mathrm{g} / \mathrm{ml}$ hygromycin-B (Roth), and $2.5 \mu \mathrm{g} / \mathrm{ml}$ blasticidin-S (BioChemika). After $48 \mathrm{~h}$, culture medium was exchanged and neurons were incubated for $24 \mathrm{~h}$ with different concentrations of compounds in a total volume of $60 \mu \mathrm{l}$ culture medium. All cultures were kept at $37^{\circ} \mathrm{C}$ and $5 \% \mathrm{CO}_{2}$. Viability of cultures was determined by the MTT assay (Gutmann et al. 2002). 
Detection of $A \beta$ Peptides

After treatment, cell supernatants were snap frozen at $-80^{\circ} \mathrm{C}$ and defrosted prior to $A \beta$ measurement. At least three separate wells were analyzed per experiment for each condition.

Cell supernatants were examined for $A \beta 38, A \beta 40$, and $A \beta 42$ content with a commercially available $A \beta$-Triplex kit from Mesoscale Discovery (MSD). Conditioned media of primary chicken telencephalic cultures were measured undiluted, whereas supernatants of $\mathrm{H} 4$ cells were diluted 1:10 with culture medium prior to measurement. For capture, $\mathrm{A} \beta 38, \mathrm{~A} \beta 40$, and $\mathrm{A} \beta 42$ specific antibodies binding the $C$-terminus of the corresponding $A \beta$ peptide (provided by MSD) were used. Bound $A \beta$ peptides were detected with a monoclonal $6 \mathrm{E} 10$ antibody and quantified by electrochemiluminescence. $A \beta$ levels in cell supernatants were evaluated in comparison to an $A \beta$ peptide standard in picogram or nanogram per milliliter. Vehicletreated control cultures were set as $100 \%$. All data of compound-treated cultures are displayed in relation to vehicle-treated controls as mean \pm standard error of mean. The total $A \beta$ content was calculated as sum of $A \beta 38$, $A \beta 40$, and $A \beta 42$.

\section{Data Analysis}

GraphPad Prism (GraphPad Software, Inc., San Diego, CA) was used to graph and analyze data.

\section{Results}

A $\beta$ Peptides are Detectable in Conditioned Media of Primary Chick Cultures and H4 Cells Expressing Human $\mathrm{APP}_{\mathrm{K} 595 \mathrm{~N} / \mathrm{M} 596 \mathrm{~L}}$

Chicken embryos express endogenous APP in the developing telencephalon and also the required enzymes for $A \beta$ formation (Carrodeguas et al. 2005). Hence, we first determined the amount of $A \beta 38, A \beta 40$, and $A \beta 42$ being released into the cell supernatant by primary E8 chicken telencephalic neurons and $\mathrm{H} 4$ cells stably expressing human $\mathrm{APP}_{\mathrm{K} 595 \mathrm{~N} / \mathrm{M} 596 \mathrm{~L}}$.

Primary chicken neurons were cultured in 24-well plates at high cell density for $48 \mathrm{~h}$. For determining $\mathrm{A} \beta$ production, $300 \mu \mathrm{l}$ of fresh medium were applied for $24 \mathrm{~h}$. H4 cells overexpressing human $\mathrm{APP}_{\mathrm{K} 595 \mathrm{~N} / \mathrm{M} 596 \mathrm{~L}}$ were plated in 96-well plates and grown to $80-90 \%$ confluency. Cells were then incubated with $60 \mu \mathrm{l}$ of fresh medium for $24 \mathrm{~h}$. Conditioned media of cultures were then analyzed for all three $A \beta$ analytes using a Triplex immunosorbent assay.
Both culture systems released $\mathrm{A} \beta 38, \mathrm{~A} \beta 40$, and $\mathrm{A} \beta 42$ peptides at detectable levels (Fig. 1a, b). H4 cells overexpressing human $\mathrm{APP}_{\mathrm{K} 595 \mathrm{~N} / \mathrm{M} 596 \mathrm{~L}}$ secreted $1.7 \pm 0.1 \mathrm{ng} / \mathrm{ml}$ $\mathrm{A} \beta 38,24 \pm 1.0 \mathrm{ng} / \mathrm{ml} \mathrm{A} \beta 40$, and $1.9 \pm 0.1 \mathrm{ng} / \mathrm{ml} \mathrm{A} \beta 42$ $(27.8 \pm 1.0 \mathrm{ng} / \mathrm{ml}$ total $\mathrm{A} \beta)$, whereas primary telencephalic neurons produced $0.11 \pm 0.01 \mathrm{ng} / \mathrm{ml} \mathrm{A} \beta 38, \quad 1.37 \pm 0.06$ $\mathrm{ng} / \mathrm{ml} \mathrm{A} \beta 40$, and $0.17 \pm 0.01 \mathrm{ng} / \mathrm{ml} \mathrm{A} \beta 42(1.64 \pm 0.08 \mathrm{ng} /$ $\mathrm{ml}$ total $\mathrm{A} \beta$ ). The $A \beta$ content in cell free culture medium was negligible (data not shown). Thus, the $\mathrm{H} 4$ cell line produced at least tenfold more $A \beta$ peptides than primary telencephalic chicken neurons.

However, the relative abundance of different $A \beta$ peptides was comparable between cultures of primary neurons and the $\mathrm{H} 4$ cell line. The main $\mathrm{A} \beta$ species detected in conditioned media was $A \beta 40$, which comprised more than $80 \%$ of all analyzed $A \beta$ forms. $A \beta 38$ and $A \beta 42$ were produced considerably less than $A \beta 40$ but both in similar quantities at approximately $7-10 \%$. Importantly, the relative
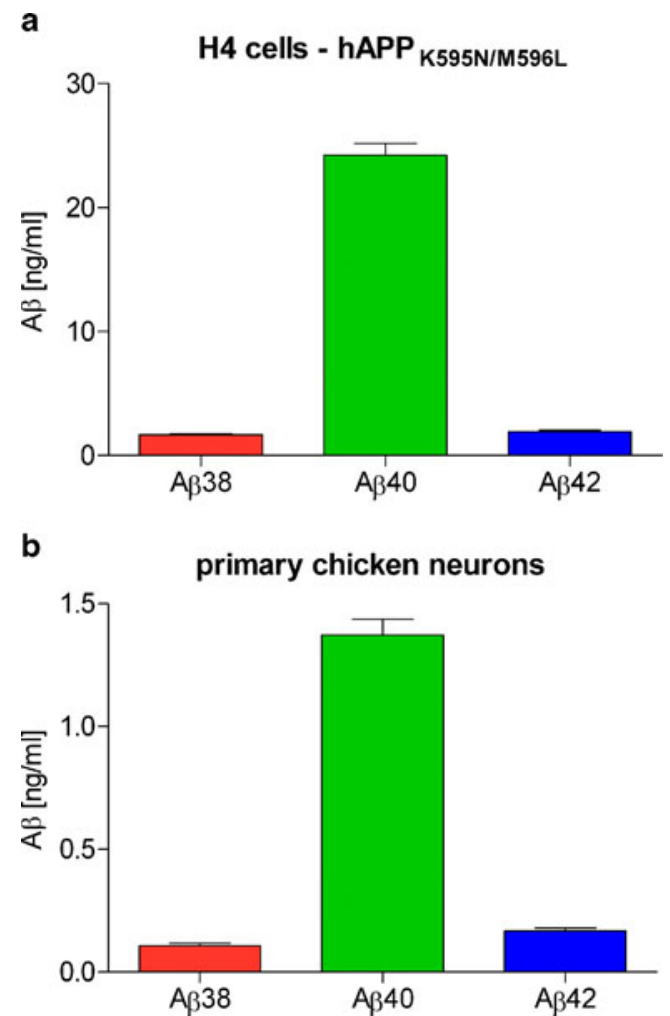

Fig. 1 Immortalized cell line produces more $A \beta$ peptides than primary neurons in vitro. a The $\mathrm{H} 4$ neuroglioma cell line overexpressing human $\mathrm{APP}_{\mathrm{K} 595 \mathrm{~N} / \mathrm{M} 596 \mathrm{~L}}$ was assessed for ectopic $\mathrm{A} \beta$ production by an immunosorbent assay. The $\mathrm{H} 4$ cell line generated more $A \beta 38, A \beta 40$, and $A \beta 42$ peptides in a $24-h$ time period than primary neurons. $A \beta 40$ was the predominant $A \beta$ peptide. b Supernatants of primary telencephalic chicken neurons were examined for endogenous $A \beta$ production by an immunosorbent assay. Primary neurons secreted detectable amounts of $\mathrm{A} \beta 38, \mathrm{~A} \beta 40$, and $\mathrm{A} \beta 42$ peptides in a $24-\mathrm{h}$ time period. $A \beta 40$ was the predominant $A \beta$ peptide. Graphs represent the individual $\mathrm{A} \beta$ content as mean \pm standard error of mean in nanogram per milliliter 
abundance of $A \beta$ peptides in both culture systems correlates with results from previously described primary chicken telencephalic cultures (Esselmann et al. 2004). Hence, primary chicken telencephalic neurons and $\mathrm{H} 4$ cells stably transfected with human $\mathrm{APP}_{\mathrm{K} 595 \mathrm{~N} / \mathrm{M} 596 \mathrm{~L} \text { produced }}$ sufficient amounts of $A \beta 38, A \beta 40$, and $A \beta 42$ peptides and could be used for further analysis.

To compare the effect of drugs modulating or inhibiting the generation of $A \beta 38, A \beta 40$, and $A \beta 42$ peptides in cultures of primary chick neurons and in the $\mathrm{H} 4$ neuroglioma cell line, we examined already characterized $\beta$ - and $\gamma$-secretase inhibitors, non-steroidal anti-inflammatory drugs (NSAIDs), and a calpain inhibitor. Almost all of the selected compounds were demonstrated to alter APP processing but not total APP protein levels (Dovey et al. 2001; Weggen et al. 2001; Mathews et al. 2002; Na et al. 2007). Hence, supernatants of compound-treated cultures were analyzed for their $\mathrm{A} \beta 38, \mathrm{~A} \beta 40$, and $\mathrm{A} \beta 42$ content by an immunosorbent assay assuming that total APP levels remained unaffected. Viability of cultures was assessed in a colorimetric MTT assay. The respective $\mathrm{IC}_{50}$ and $E_{\max }$ of each compound are summarized in Table 1.

BACE-1 Inhibition is More Potent in Primary Neurons than in the H4 Cell Line Expressing Human APP with the Swedish Double Mutation

First, we examined the $\beta$-secretase inhibitor IV, a commercially available BACE-1 inhibitor, which has been previously shown to inhibit BACE-1 in a HEK cell culture model overexpressing $\mathrm{APP}_{\mathrm{NFEV}}$ at an $\mathrm{IC}_{50}$ of $15 \mathrm{nM}$ (Stachel et al. 2004). When the $\beta$-secretase inhibitor IV was applied on the $\mathrm{H} 4$ cell line, a concentrationdependent decrease in $\mathrm{A} \beta$ secretion $\left(\mathrm{IC}_{50} \mathrm{~A} \beta 38=92.3\right.$ $\left.\mathrm{nM}, \mathrm{IC}_{50} \mathrm{~A} \beta 40=124.7 \mathrm{nM}, \mathrm{IC}_{50} \mathrm{~A} \beta 42=215.6 \mathrm{nM}\right)$ was evident (Fig. 2a), but the reduction occurred at distinctly higher concentrations than in the HEK cell culture model (Stachel et al. 2004). In contrast, the $A \beta 38, A \beta 40$, and $A \beta 42$ content declined in primary neuronal cultures already at $5 \mathrm{nM}$ (Fig. 2b), and $\mathrm{A} \beta 42$ was reduced by more than $50 \%$ at an inhibitor concentration of $25 \mathrm{nM}$, indicating that the extent of inhibition in telencephalic neurons complies with the reported $\mathrm{IC}_{50}$ in HEK cells (Stachel et al. 2004). Unexpectedly, $A \beta 40$ and $A \beta 42$ production was not completely inhibited by the BACE-1 inhibitor (Table 1). The effect of the $\beta$-secretase inhibitor on $A \beta$ cleavage was not due to compound toxicity as no reduction in cell viability was observed (data not shown). Altogether, BACE-1 inhibition was approximately tenfold more potent in primary cells than in the human neuroglioma cell line expressing human $\mathrm{APP}_{\mathrm{K} 595 \mathrm{~N} / \mathrm{M} 596 \mathrm{~L}}$.

$\gamma$-Secretase Inhibition is More Pronounced in the H4 Neuroglioma Cell Line

Next, we addressed the effect of two $\gamma$-secretase inhibitors, DAPM and DAPT, in our two culture models. DAPM was shown to reduce secretion of $A \beta$ monomers in $\mathrm{CHO}$ cells expressing human APP751 $1_{\text {Val717Phe }}$ at an $\mathrm{IC}_{50}$ of approximately $100 \mathrm{nM}$ by a highly sensitive immunoprecipitation and western blotting method (Walsh et al. 2002). DAPT was reported to abolish $A \beta 42$ formation in primary human neuronal cultures at an $\mathrm{IC}_{50}$ of $200 \mathrm{nM}$ (Dovey et al. 2001).

Table 1 Effects of pharmacological modulators on $A \beta$ formation

\begin{tabular}{|c|c|c|c|c|c|c|c|}
\hline & & \multicolumn{2}{|l|}{$\mathrm{A} \beta 38$} & \multicolumn{2}{|l|}{$\mathrm{A} \beta 40$} & \multicolumn{2}{|l|}{$\mathrm{A} \beta 42$} \\
\hline & & $\mathrm{IC}_{50}$ & $E_{\max }$ & $\mathrm{IC}_{50}$ & $E_{\max }$ & $\mathrm{IC}_{50}$ & $E_{\max }$ \\
\hline \multirow[t]{2}{*}{ Beta secretase inhibitor IV } & $\mathrm{H} 4$ cells $-\mathrm{hAPP} \mathrm{K}_{\mathrm{K} 95 \mathrm{~N} / \mathrm{N} 596 \mathrm{~L}}$ & $92 \mathrm{nM}$ & $88 \%$ & $125 \mathrm{nM}$ & $79 \%$ & $216 \mathrm{nM}$ & $86 \%$ \\
\hline & Primary chicken neurons & $3.7 \mathrm{nM}$ & $91 \%$ & $4.7 \mathrm{nM}$ & $76 \%$ & $4.8 \mathrm{nM}$ & $70 \%$ \\
\hline \multirow[t]{2}{*}{ DAPM } & $\mathrm{H} 4$ cells $-\mathrm{hAPP} \mathrm{K}_{595 \mathrm{~N} / \mathrm{N} 596 \mathrm{~L}}$ & $20 \mathrm{nM}$ & $100 \%$ & $23 \mathrm{nM}$ & $100 \%$ & $26 \mathrm{nM}$ & $100 \%$ \\
\hline & Primary chicken neurons & $63 \mathrm{nM}$ & $100 \%$ & $100 \mathrm{nM}$ & $100 \%$ & $107 \mathrm{nM}$ & $100 \%$ \\
\hline \multirow[t]{2}{*}{ DAPT } & $\mathrm{H} 4$ cells $-\mathrm{hAPP} \mathrm{K}_{\mathrm{K} 55 \mathrm{~N} / \mathrm{N} 596 \mathrm{~L}}$ & $50 \mathrm{nM}$ & $100 \%$ & $61 \mathrm{nM}$ & $100 \%$ & $64 \mathrm{nM}$ & $100 \%$ \\
\hline & Primary chicken neurons & $75 \mathrm{nM}$ & $100 \%$ & $93 \mathrm{nM}$ & $100 \%$ & $101 \mathrm{nM}$ & $100 \%$ \\
\hline \multirow[t]{2}{*}{ Sulindac sulfide } & $\mathrm{H} 4$ cells $-\mathrm{hAPP} \mathrm{K}_{\mathrm{K} 55 \mathrm{~N} / \mathrm{N} 596 \mathrm{~L}}$ & - & - & - & - & $76 \mu \mathrm{M}$ & $100 \%$ \\
\hline & Primary chicken neurons & - & - & - & - & $33 \mu \mathrm{M}$ & $100 \%$ \\
\hline \multirow[t]{2}{*}{$\mathrm{CW}$} & $\mathrm{H} 4$ cells $-\mathrm{hAPP} \mathrm{K}_{\mathrm{K} 95 \mathrm{~N} / \mathrm{N} 596 \mathrm{~L}}$ & - & - & - & - & $41 \mu \mathrm{M}$ & $100 \%$ \\
\hline & Primary chicken neurons & - & - & - & - & $17 \mu \mathrm{M}$ & $100 \%$ \\
\hline \multirow[t]{2}{*}{ Calpeptin } & $\mathrm{H} 4$ cells $-\mathrm{hAPP} \mathrm{K}_{\mathrm{K} 55 \mathrm{~N} / \mathrm{N} 596 \mathrm{~L}}$ & $4.0 \mu \mathrm{M}$ & $100 \%$ & $7.4 \mu \mathrm{M}$ & $100 \%$ & - & - \\
\hline & Primary chicken neurons & $5.0 \mu \mathrm{M}$ & $100 \%$ & - & - & - & - \\
\hline
\end{tabular}

The $\mathrm{IC}_{50}$ and $E_{\max }$ values for $\mathrm{A} \beta 38, \mathrm{~A} \beta 40$, and $\mathrm{A} \beta 42$ generation in $\mathrm{H} 4$ cells overexpressing human $\mathrm{APP}_{\mathrm{K} 595 \mathrm{~N} / \mathrm{M} 596 \mathrm{~L}}$ and in primary telencephalic chicken neurons are summarized for each individual compound 
a

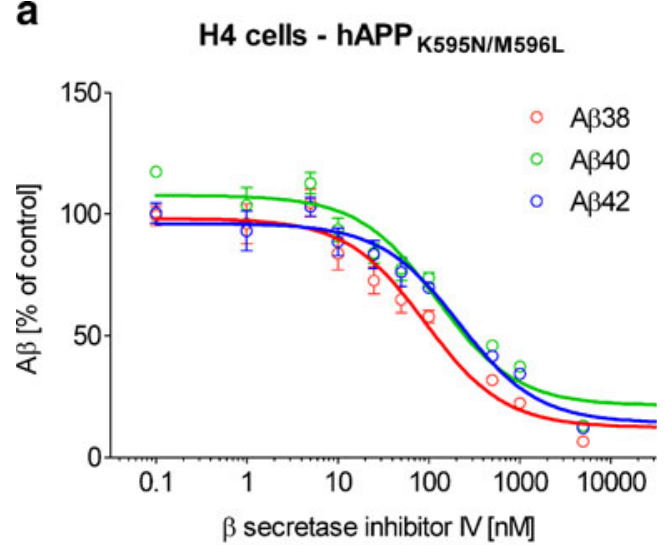

b

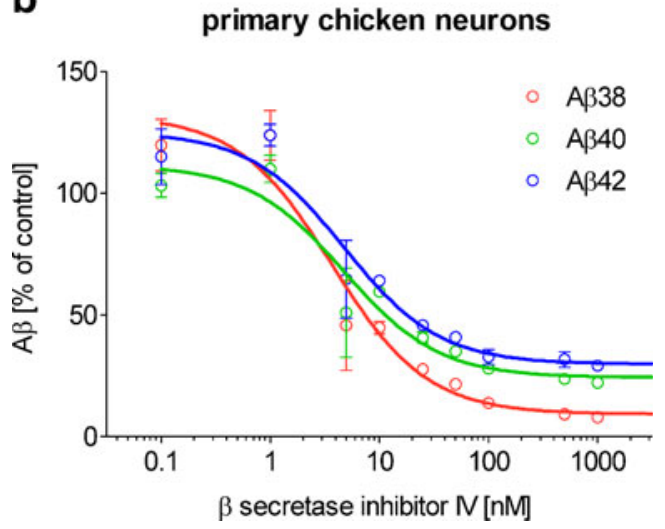

Fig. 2 BACE-1 inhibition is more efficacious in primary neurons. H4 cells overexpressing human $\mathrm{APP}_{\mathrm{K} 595 \mathrm{~N} / \mathrm{M} 596 \mathrm{~L}}$ and primary telencephalic chicken neurons were treated with different concentrations of the $\beta$-secretase inhibitor IV for $24 \mathrm{~h}$. A $\beta$ content of cell supernatants was determined by an immunosorbent assay. a In $\mathrm{H} 4$ cells, levels of $\mathrm{A} \beta 38$, $\mathrm{A} \beta 40$, and $\mathrm{A} \beta 42$ peptides decreased in a concentration-dependent manner. b In primary telencephalic neurons, $A \beta 38, A \beta 40$, and $A \beta 42$ levels declined already dramatically at low nanomolar concentrations of the BACE-1 inhibitor, in contrast to $\mathrm{H} 4$ cells. Graphs represent the individual $A \beta$ content in percent of vehicle-treated cultures as mean \pm standard error of mean

DAPM reduced secretion of all three $A \beta$ species in $\mathrm{H} 4$ cells $\left(\mathrm{IC}_{50} \mathrm{~A} \beta 38=19.9 \mathrm{nM}, \mathrm{IC}_{50} \mathrm{~A} \beta 40=23.1 \mathrm{nM}\right.$, $\mathrm{IC}_{50} \mathrm{~A} \beta 42=25.9 \mathrm{nM}$ ) but conversely caused an increase of all three $A \beta$ forms at low nanomolar concentrations (Fig. 3a). In cultures of primary telencephalic neurons, DAPM also decreased formation of $\mathrm{A} \beta$ peptides $\left(\mathrm{IC}_{50}\right.$ $\mathrm{A} \beta 38=61.9 \mathrm{nM}, \mathrm{IC}_{50} \mathrm{~A} \beta 40=99.7 \mathrm{nM}, \mathrm{IC}_{50} \mathrm{~A} \beta 42=$ $106.9 \mathrm{nM}$ ) but at higher concentrations than in $\mathrm{H} 4$ cultures. Also, no increase in $A \beta$ secretion was observed in primary cultures at any concentration of the $\gamma$-secretase inhibitor (Fig. 3b). Hence, the effect of DAPM was slightly more potent in $\mathrm{H} 4$ cells overexpressing human $\mathrm{APP}_{\mathrm{K} 595 \mathrm{~N} / \mathrm{M} 596 \mathrm{~L}}$ than in primary telencephalic neurons. DAPM had no effect on cell viability in both culture systems (data not shown).
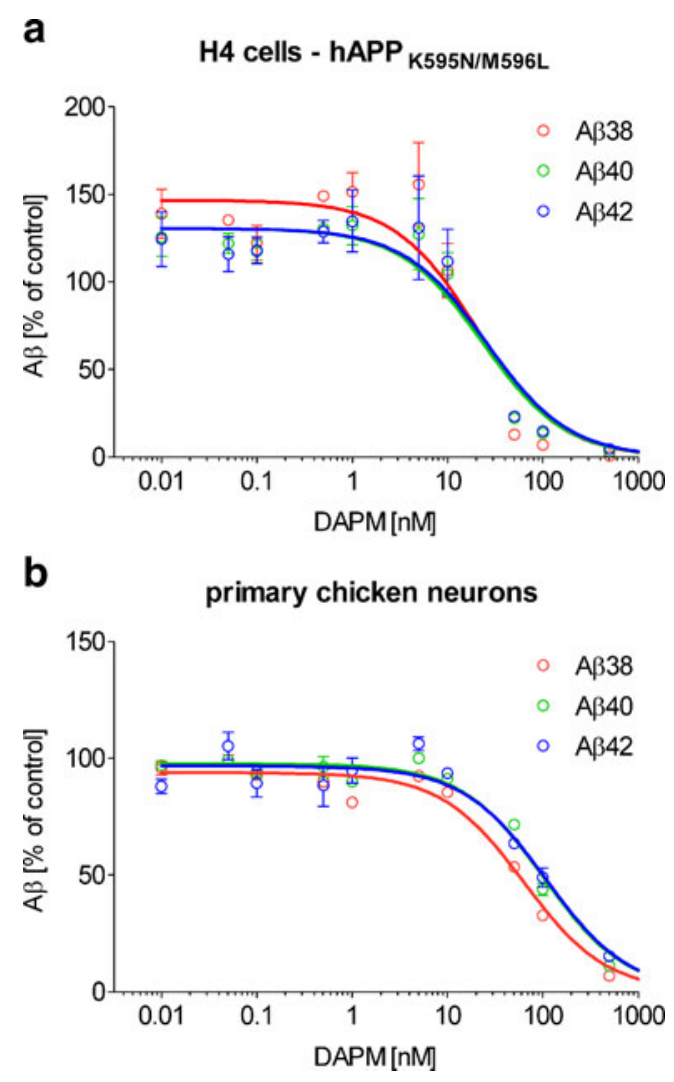

Fig. 3 The $\gamma$-secretase inhibitor DAPM reduces $A \beta$ formation in both culture models. $\mathrm{H} 4$ cells overexpressing human $\mathrm{APP}_{\mathrm{K} 595 \mathrm{~N} / \mathrm{M} 596 \mathrm{~L}}$ and primary telencephalic chicken neurons were treated with different concentrations of the $\gamma$-secretase inhibitor DAPM for $24 \mathrm{~h}$. A $\beta$ content of cell supernatants was determined by an immunosorbent assay. a Levels of $\mathrm{A} \beta 38, \mathrm{~A} \beta 40$, and $\mathrm{A} \beta 42$ peptides declined dramatically starting at a concentration of $50 \mathrm{nM}$ DAPM in the $\mathrm{H} 4$ cell line. b $\mathrm{A} \beta 38, \mathrm{~A} \beta 40$, and $\mathrm{A} \beta 42$ content decreased at a concentration of $50 \mathrm{nM}$ DAPM in primary neurons but not as pronounced as in the $\mathrm{H} 4$ cell line. Graphs represent the individual A $\beta$ content in percent of vehicle-treated cultures as mean \pm standard error of mean

The second $\gamma$-secretase inhibitor, DAPT, inhibited APP cleavage in $\mathrm{H} 4$ cells $\left(\mathrm{IC}_{50} \mathrm{~A} \beta 38=50.3 \mathrm{nM}, \mathrm{IC}_{50} \mathrm{~A} \beta 40=\right.$ $\left.61.4 \mathrm{nM}, \mathrm{IC}_{50} \mathrm{~A} \beta 42=63.8 \mathrm{nM}\right)$ but also increased the formation of all three $A \beta$ species at $10 \mathrm{nM}$ (Fig. 4a). Similarly, $A \beta 38, A \beta 40$, and $A \beta 42$ peptide levels decreased in supernatants of primary neurons $\left(\mathrm{IC}_{50} \mathrm{~A} \beta 38=71.2 \mathrm{nM}\right.$, $\mathrm{IC}_{50} \mathrm{~A} \beta 40=92.8 \mathrm{nM}, \mathrm{IC}_{50} \mathrm{~A} \beta 42=100.8 \mathrm{nM}$ ), but no dramatic increase in $A \beta$ levels was observed at low nanomolar concentrations of the compound in contrast to $\mathrm{H} 4$ cells (Fig. 4b). Viability of primary neurons and H4 cells was not affected by DAPT treatment (data not shown). As in DAPM treated cultures, the effect of DAPT was slightly more pronounced in $\mathrm{H} 4$ cells stably expressing human $\mathrm{APP}_{\mathrm{K} 595 \mathrm{~N} / \mathrm{M} 596 \mathrm{~L}}$ than in primary telencephalic neurons. However, the $\mathrm{IC}_{50}$ of DAPT and DAPM for 

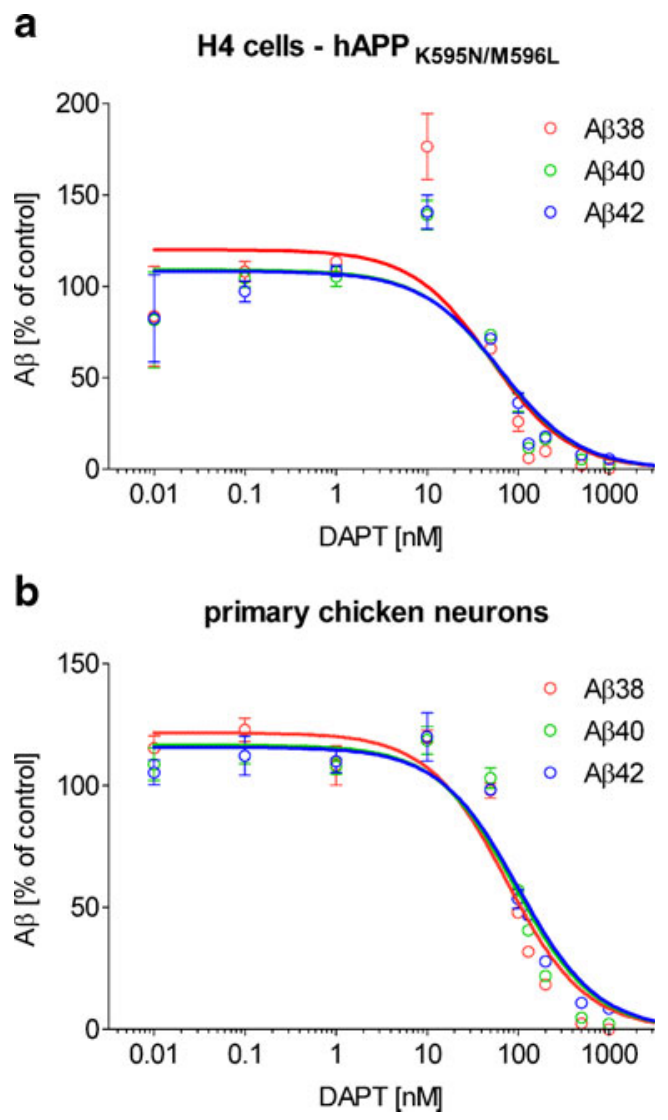

Fig. 4 The $\gamma$-secretase inhibitor DAPT reduces $\mathrm{A} \beta$ formation in primary and immortalized cells. H4 cells overexpressing human $\mathrm{APP}_{\mathrm{K} 595 \mathrm{~N} / \mathrm{M} 596 \mathrm{~L}}$ and primary telencephalic chicken neurons were treated with different concentrations of the $\gamma$-secretase inhibitor DAPT for $24 \mathrm{~h}$. A $\beta$ content of cell supernatants was determined by an immunosorbent assay. a In the $\mathrm{H} 4$ cell line, $\mathrm{A} \beta 38, \mathrm{~A} \beta 40$, and $\mathrm{A} \beta 42$ levels started to be reduced at a concentration of $50 \mathrm{nM}$ DAPT. b In primary telencephalic neurons, $A \beta$ peptides started to diminish at a concentration of $100 \mathrm{nM}$ DAPT. Graphs represent the individual $\mathrm{A} \beta$ content in percent of vehicle-treated cultures as mean \pm standard error of mean

A $\beta 42$ cleavage was not higher in primary neurons when compared to the published efficacies of these inhibitors. Hence, both culture systems reproduced the reported effects of the selected $\gamma$-secretase inhibitors.

Two NSAIDs Modulate Processing of A $\beta$ Peptides in Primary Neurons at Lower Concentrations than in the H4 Cell Line

A subset of non-steroidal anti-inflammatory drugs (NSAIDs) has been shown to interfere with APP processing by modulating $\gamma$-secretase-mediated APP cleavage independent of their impact on cyclooxygenase-1 (COX1) and COX2 activity (Weggen et al. 2001). Here, we investigated the effect of sulindac sulfide and $\mathrm{CW}$ in our cell culture models. The non-selective COX-inhibitor sulindac sulfide has previously been reported to reduce $\mathrm{A} \beta 42$ levels by $\geq 50 \%$ at concentrations of $80-100 \mu \mathrm{M}$ in several cell lines overexpressing human wildtype or mutant APP (Weggen et al. 2001). Concomitant with the decrease in $A \beta 42$ content, an increase in $A \beta 38$ was detected in supernatants of treated cultures (Weggen et al. 2001). In CHO cells expressing human APP containing the Swedish mutation, $40 \mu \mathrm{M}$ sulindac sulfide reduced $\mathrm{A} \beta 42$ secretion to $\sim 45 \%$ (Weggen et al. 2003). The second NSAID we examined was the cell-permeable benzoate $\mathrm{CW}$, which was identified in a computer-based structural similarity search for NSAIDs. CW has been demonstrated to reduce $A \beta 42$ levels at a concentration of $100 \mu \mathrm{M}$ (Okochi et al. 2006).

In $\mathrm{H} 4$ cells expressing human $\mathrm{APP}_{\mathrm{K} 595 \mathrm{~N} / \mathrm{M} 596 \mathrm{~L}}$, sulindac sulfide enhanced generation of $\mathrm{A} \beta 38$ peptides at low micromolar concentration (Fig. 5a). A decrease in $A \beta 42$ levels appeared at a concentration of $50 \mu \mathrm{M}$ with $\mathrm{A} \beta 42$ levels being reduced to $75.0 \pm 7.1 \%$. The $\mathrm{A} \beta 42$ content declined further to $39.3 \pm 2.0 \%$ at $100 \mu \mathrm{M}$, whereas $\mathrm{A} \beta 40$ production remained still unaltered. At $150 \mu \mathrm{M}$, sulindac sulfide started to display already some minor cell toxicity in the viability assay (data not shown). Thus, the concentration of sulindac sulfide necessary to diminish $A \beta 42$ levels by $50 \%$ was between 75 and $100 \mu \mathrm{M}$. The different extent of sulindac sulfide-mediated modulation of $A \beta 38$ and A $\beta 42$ levels was not unexpected. Analyses of different PS1 mutations associated with familial Alzheimer's disease (FAD) revealed that sulindac sulfide can modulate $A \beta 38$ and $A \beta 42$ formation independently (Page et al. 2008).

In contrast to $\mathrm{H} 4$ cells, secretion of $\mathrm{A} \beta 42$ peptides was already reduced at lower micromolar concentrations of sulindac sulfide in primary neuronal cultures (Fig. 5b). A $\beta 38$ content started to increase at $25 \mu \mathrm{M}$ to approximately $149.7 \pm 6.4 \%$, whereas $A \beta 42$ levels decreased concomitantly to $54.7 \pm 6.4 \%$. At $50 \mu \mathrm{M}, \mathrm{A} \beta 38$ levels did not rise any further, but $A \beta 42$ continued to drop to $25.3 \pm 2.1 \%$, and also $A \beta 40$ levels started to decline. At concentrations beginning with $75 \mu \mathrm{M}$, the NSAID started to become toxic in primary cultures (data not shown). Hence, the concentration of sulindac sulfide required to reduce $A \beta 42$ levels in primary chick cultures by $50 \%$ is at $\sim 33 \mu \mathrm{M}$. This also complies with the efficacy of sulindac sulfide described in HEK cell (Weggen et al. 2003), whereas sulindac sulfide was surprisingly less efficacious in the stable $\mathrm{H} 4$ cell line expressing human $\mathrm{APP}_{\mathrm{K} 595 \mathrm{~N} / \mathrm{M} 596 \mathrm{~L}}$.

$\mathrm{CW}$ started to elevate $\mathrm{A} \beta 38$ and moderately reduce A $\beta 42$ levels in $\mathrm{H} 4$ cells at a concentration of $50 \mu \mathrm{M}$ (Fig. 6a). At $100 \mu \mathrm{M}, \mathrm{A} \beta 38$ increased to $287.5 \pm 31.2 \%$, whereas $\mathrm{A} \beta 42$ was further reduced to $16.0 \pm 1.8 \%$ compared to vehicle-treated cultures. At 150 and $200 \mu \mathrm{M}$, $A \beta 38$ and $A \beta 40$ secretion started also to decline, although no cell toxicity was observed in the MTT viability assay at these concentrations (data not shown). Therefore, CW 
a

\section{H4 cells - hAPP K595N/M596L}

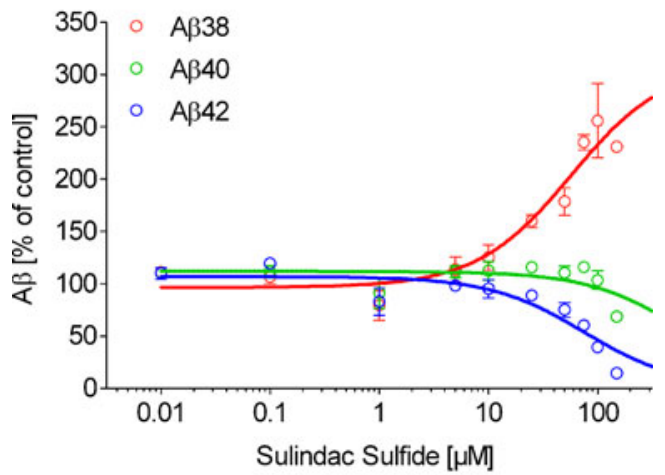

b

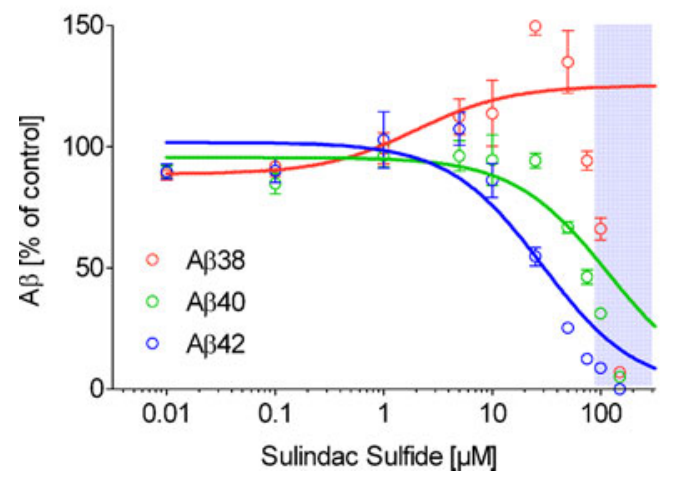

Fig. 5 Sulindac sulfide modulates $A \beta$ processing more efficaciously in primary neurons than in the $\mathrm{H} 4$ cell line. $\mathrm{H} 4$ cells overexpressing human $\mathrm{APP}_{\mathrm{K} 595 \mathrm{~N} / \mathrm{M} 596 \mathrm{~L}}$ and primary telencephalic chicken neurons were treated with different concentrations of the NSAID sulindac sulfide for $24 \mathrm{~h}$. A $\beta$ content of cell supernatants was determined by an immunosorbent assay. a In the $\mathrm{H} 4$ cell line, A $\beta 42$ levels started to decline at a concentration of $50 \mu \mathrm{M}$. b In primary telencephalic neurons, $A \beta 42$ levels dropped already at a concentration of $25 \mu \mathrm{M}$. The blue bar indicates toxic concentrations. Graphs represent the individual $\mathrm{A} \beta$ content in percent of vehicle-treated cultures as mean \pm standard error of mean

decreased $\mathrm{A} \beta 42$ levels in $\mathrm{H} 4$ cells by $50 \%$ at concentrations between 50 and $100 \mu \mathrm{M}$.

In cultures of primary telencephalic neurons, moderate changes in $A \beta 38$ and $A \beta 42$ peptide were already detected at $5 \mu \mathrm{M} \mathrm{CW}$ (Fig. 6b). At $10 \mu \mathrm{M}$, an increase of $127.9 \pm$ $0.9 \% \mathrm{~A} \beta 38$ was observed, whereas $\mathrm{A} \beta 42$ levels declined to $63.6 \pm 2.4 \%$. The effect of $\mathrm{CW}$ was further potentiated at $50 \mu \mathrm{M}$, with $\mathrm{A} \beta 38$ levels rising to $159.3 \pm 8.0 \%$ and $A \beta 42$ falling to $29.9 \pm 1.2 \%$. Therefore, $\mathrm{CW}$ diminished $\mathrm{A} \beta 42$ levels by $50 \%$ at $\sim 17 \mu \mathrm{M}$ in primary neurons. The $\mathrm{A} \beta 40$ content remained unchanged up to $50 \mu \mathrm{M}$ compared to vehicle-treated cells. However, starting from $100 \mu \mathrm{M}$, levels of all $\mathrm{A} \beta$ species declined progressively with increasing concentration of the NSAID. The reduction of $\mathrm{A} \beta$ species at the two highest concentrations was due to neuronal toxicity of the compound as $\mathrm{CW}$ affected cell viability at 150 and $200 \mu \mathrm{M}$ but not at lower concentrations a

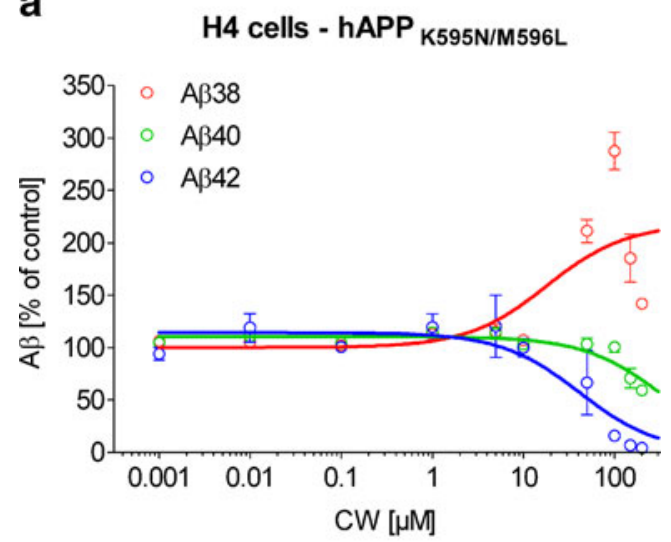

b

primary chicken neurons

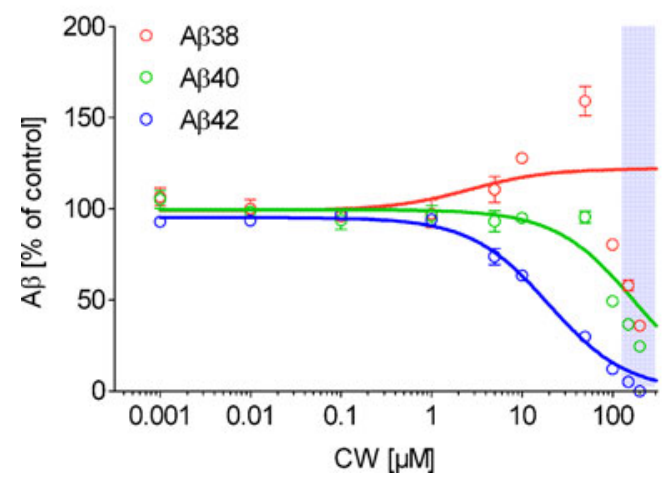

Fig. 6 Compound $\mathrm{CW}$ modulates $\mathrm{A} \beta 42$ formation at lower concentrations in primary neurons than in the $\mathrm{H} 4$ cell line. Different concentrations of the non-steroidal anti-inflammatory drug $\mathrm{CW}$ were administered in cultures of $\mathrm{H} 4$ cells overexpressing human $\mathrm{APP}_{\mathrm{K} 595 \mathrm{~N} / \mathrm{M} 596 \mathrm{~L}}$ and primary telencephalic chicken neurons. Cell supernatants were assessed for $A \beta$ content by an immunosorbent assay. a In the $\mathrm{H} 4$ cell line, $\mathrm{A} \beta 42$ levels started to diminish at a concentration of $50 \mu \mathrm{M}$. b In primary telencephalic neurons, $\mathrm{A} \beta 42$ levels started to decrease already at a concentration of $5 \mu \mathrm{M}$. The blue bar indicates toxic concentrations. Graphs represent the individual $\mathrm{A} \beta$ content in percent of vehicle-treated cultures as mean \pm standard error of mean

(data not shown). As sulindac sulfide, CW was also more efficacious in modulating APP processing in primary telencephalic neurons than in the H4 cell line ectopically expressing human mutant APP.

Interfering with Calpain Signaling Affects $A \beta 42$ Formation Only in Primary Chicken Neurons

An unregulated intracellular increase of $\mathrm{Ca}^{2+}$ and elevated activity of the $\mathrm{Ca}^{2+}$-dependent calpain proteases has been linked with inducing cell death (Harwood et al. 2005; Golstein and Kroemer 2007). Further, calpain inhibitors have been demonstrated to counteract excitotoxic insults (Hara and Snyder 2007). But besides their role in cell death, calpains have also been implicated in APP processing since inhibition of calpain activity was demonstrated to increase 
A 342 production in cell cultures (Klafki et al. 1996; Zhang et al. 1999; Mathews et al. 2002). The cell-permeable calpain inhibitor calpeptin has been reported to elevate secretion of $A \beta 42$ but not of $A \beta 40$ at a concentration of $10 \mu \mathrm{M}$ in a murine cell line ectopically expressing human wildtype APP695 and also in untransfected murine cells (Mathews et al. 2002).

Calpeptin did not evoke any dramatic changes in $\mathrm{H} 4$ cells expressing mutant human APP up to a concentration

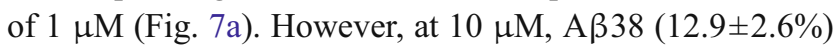
and $\mathrm{A} \beta 40(35.5 \pm 2.2 \%)$ peptide levels decreased sharply, whereas $\mathrm{A} \beta 42(90.3 \pm 6.0 \%)$ remained almost on the same level as in vehicle control cultures.

Similarly, no effect of calpeptin was observed in cultures of primary chicken neurons up to a concentration of $1 \mu \mathrm{M}$ (Fig. 7b). In contrast to $\mathrm{H} 4$ cells, calpeptin increased $\mathrm{A} \beta 42$ levels to $259.3 \pm 7.3 \%$ at a concentration of $10 \mu \mathrm{M}$, whereas A $\beta 40$ remained almost unchanged at $89.9 \pm 3.8 \%$. The $A \beta 38$

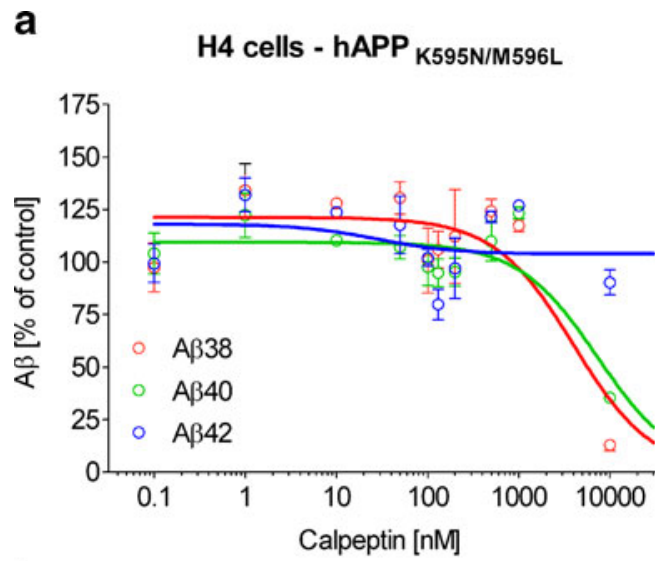

b primary chicken neurons

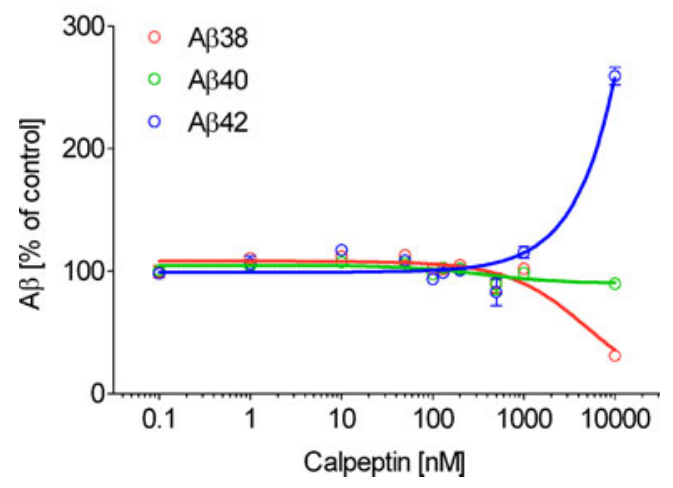

Fig. 7 Calpain inhibition increases $\mathrm{A} \beta 42$ formation in primary but not immortalized cells. H4 cells overexpressing human $\mathrm{APP}_{\mathrm{K} 595 \mathrm{~N} / \mathrm{M} 596 \mathrm{~L}}$ and primary telencephalic chicken neurons were treated with different concentrations of calpeptin for $24 \mathrm{~h}$. A $\beta$ content of cell supernatants was determined by an immunosorbent assay. a No modulation of $\mathrm{A} \beta 42$ levels was observed in $\mathrm{H} 4$ cells. b In contrast, A $\beta 42$ content was increased at $10 \mu \mathrm{M}$ in primary neuronal cultures. Graphs represent the individual $\mathrm{A} \beta$ content in percent of vehicle-treated cultures as mean \pm standard error of mean content in supernatants was reduced to $31.1 \pm 1.8 \%$. No toxicity of calpeptin was observed in primary and $\mathrm{H} 4$ cell cultures (data not shown). Hence, primary telencephalic neurons but not $\mathrm{H} 4$ cells expressing human $\mathrm{APP}_{\mathrm{K} 595 \mathrm{~N} / \mathrm{M} 596 \mathrm{~L}}$ increased $A \beta 42$ generation at a calpeptin concentration of $10 \mu \mathrm{M}$. Therefore, primary chicken neurons but not $\mathrm{H} 4$ cells reproduced the previously reported effect of calpeptin on APP processing (Mathews et al. 2002).

\section{Discussion}

Increased formation of toxic $A \beta 42$ peptides is characteristic for sporadic and familial forms of Alzheimer's disease. Therefore, compounds targeting $\beta$ - and $\gamma$-secretase activities were developed in recent years to render formation of aberrant $A \beta 42$. Most in vitro screens identifying such compounds were performed in immortalized cells expressing mutant human APP. Here, we compared primary chicken telencephalic neurons with a human neuroglioma cell line overexpressing human APP harboring the Swedish double mutation to decipher differences in their response to known modulators of APP processing.

We chose chicken telencephalic rather than rodent neurons as source for primary cultures since chick $A \beta 42$ is identical to the human sequence and primary chicken telencephalic neurons were previously demonstrated to secrete detectable amounts of $A \beta 1-37, A \beta 1-38, A \beta 1-39$, $A \beta 1-40$, and $A \beta 1-42$ in vitro by using an immunoprecipitation and Western Blot protocol (Esselmann et al. 2004). In accordance, we confirmed formation of $A \beta 38, A \beta 40$, and $A \beta 42$ peptides in cell supernatants of primary chicken telencephalic neurons using an electrochemiluminescence based immunosorbent assay. Similar to human cerebrospinal fluid (Lewczuk et al. 2004), A $\beta 40$ was the predominant $A \beta$ species produced by primary chicken neurons and the neuroglioma cell line. H4 cells overexpressing human mutant APP secreted at least tenfold more $A \beta$ peptides than chicken neurons, but the $A \beta 42 / A \beta 40$ ratio was comparable in supernatants of $\mathrm{H} 4$ cells and primary telencephalic neurons.

Since both culture systems produced desirable levels of A $\beta$ peptides, we administered compounds known to inhibit or modulate APP cleavage and determined production of $A \beta 38, A \beta 40$, and $A \beta 42$ peptides.

In cultures treated with the $\beta$-secretase inhibitor IV, we observed a more severe inhibition of $\beta$-secretase activity in primary neurons than in the $\mathrm{H} 4$ cell line expressing human APP harboring the Swedish double mutation. This appears particularly interesting as this mutation has been associated with accelerated APP cleavage by $\beta$-secretase. Other groups also demonstrated that BACE-1 inhibition is approximately tenfold less powerful in cells expressing 
human $\mathrm{APP}_{\mathrm{K} 595 \mathrm{~N} / \mathrm{M} 596 \mathrm{~L}}$ compared to cells overexpressing wildtype APP (Hussain et al. 2007; Yamakawa et al. 2010). Recently, the difference in $\beta$-secretase inhibition has been linked to different subcellular localization of wildtype APP and $\mathrm{APP}_{\mathrm{K} 595 \mathrm{~N} / \mathrm{M} 596 \mathrm{~L}}$ (Koo and Squazzo 1994; Haass et al. 1995; Yamakawa et al. 2010). Similarly, the FAD-linked mutations $\mathrm{APP}_{\mathrm{V} 717 \mathrm{~F}}, \mathrm{PS}_{\mathrm{M} 146 \mathrm{~L}}$, and $\mathrm{PS}_{\mathrm{L} 166 \mathrm{P}}$, which all affect $\gamma$-secretase cleavage, are less sensitive to $\gamma$-secretase inhibitors (Xia et al. 2000; Czirr et al. 2007). Moreover, cells transfected with $\mathrm{APP}_{\mathrm{V} 717 \mathrm{~F}}$ or different PS1 mutations display altered secretion of $A \beta$ peptides in response to sulindac sulfide treatment compared to cells transfected with the respective wildtype protein (Weggen et al. 2003; Czirr et al. 2007; Page et al. 2008). Thus, secretase inhibitors and modulators exhibit different potencies and effects in cellular assays depending on the presence or absence of FAD-linked mutations. Since the vast majority of patients who suffer from sporadic AD encode wildtype and not mutant $A P P$ or $P S 1$, screening compounds in cells expressing wildtype APP and PS1 reflects more on human pathology and also defines the efficacy of a substance more precisely.

Both $\gamma$-secretase inhibitors, DAPM and DAPT, evoked a dose-dependent decrease in $\mathrm{A} \beta 38, \mathrm{~A} \beta 40$, and $A \beta 42$ levels, but the reduction was more pronounced in the neuroglioma cell line than in primary telencephalic neurons. Indeed, DAPT has been demonstrated to inhibit A $\beta$ formation more severely in a HEK293 cell line expressing human APP751 containing the Swedish mutation than in primary neuronal cultures with DAPT exhibiting a five- to tenfold lower potency in human and mouse primary cultures (Dovey et al. 2001). Similarly to DAPT, a selective tyrosine kinase inhibitor, which has been suggested to indirectly regulate $\gamma$-secretase activity, reduced $A \beta$ production faster in $\mathrm{N} 2 \mathrm{a}$ cells producing Swedish mutant APP than in primary cortical neurons (Netzer et al. 2003). As $\beta$-secretase cleavage is a prerequisite for $\gamma$-secretase-mediated APP processing, APP containing the Swedish mutation simply increases the intracellular concentration of $\gamma$-secretase substrate and thus provides a higher and more favorable substrate/ enzyme ratio than in primary neurons (Citron et al. 1992; Yang et al. 2003). Subsequently, an enzymatic reaction at a high substrate/enzyme ratio enables a more efficient inhibition of APP cleavage by secretase inhibitors. A comparison of $\gamma$-secretase inhibitors in cell lines expressing either wildtype or APP containing the Swedish mutation would address the influence of Swedish mutant APP on $\gamma$-secretase inhibition. When DAPT was administered in vivo, the actual concentration of DAPT in brain tissue ( $\sim 200 \mathrm{nM}$ and higher) that reduced total $\mathrm{A} \beta$ content was in excess of the $\mathrm{IC}_{50}$ in primary cultures $\left(\mathrm{IC}_{50} \mathrm{~A} \beta\right.$ total $=115 \mathrm{nM}$ ) (Dovey et al. 2001). Thus, in vivo DAPT data indicate that primary neurons are more likely to define the potency of a $\gamma$-secretase inhibitor for in vivo administration than cell lines. Beside the reduction in $A \beta$ levels, we also observed an increase in $A \beta 38, A \beta 40$, and $\mathrm{A} \beta 42$ formation at DAPM and DAPT concentrations below their respective $\mathrm{IC}_{50}$. Such an effect has already been described for a difluoroketoamide-based $\gamma$-secretase inhibitor, which also increased $\mathrm{A} \beta 42$ levels at subinhibitory concentrations (Durkin et al. 1999).

In contrast, modulation of $\gamma$-secretase activity by NSAIDs appeared more severe in primary cultures. A comparison of N2a cells expressing human APP bearing the Swedish mutation and primary rat cortical neurons also indicated a stronger reduction of $A \beta 40$ and $A \beta 42$ levels in primary cultures at a concentration of $25 \mu \mathrm{M}$ (Gasparini et al. 2004), although we only observed a reduction in $A \beta 40$ levels at very high sub-lethal and lethal concentrations. The reduced potency of NSAIDs in the neuroglioma cell line is, unlike BACE-1 inhibitors, independent of the APP Swedish double mutation. CHO cells transfected with $\mathrm{APP}_{\mathrm{K} 595 \mathrm{~N} / \mathrm{M} 596 \mathrm{~L}}$ secrete the same levels of $A \beta 42$ after treatment with sulindac sulfide as cells expressing wildtype APP (Weggen et al. 2003). However, primary neurons and cell lines differ in their APP content. Whereas primary neurons produce endogenous APP at physiological levels, cell lines highly overexpress ectopic APP suggesting that the modulating activity of NSAIDs is dependent on the amount and availability of APP substrate. Such a scenario would assume that sulindac sulfide and $\mathrm{CW}$ directly interact with APP. Indeed, a study using labeled $\gamma$-secretase modulators (GSM) revealed a direct interaction of GSMs with residues of the beta-amyloid peptide rather than with the core proteins of the $\gamma$-secretase complex (Kukar et al. 2008). Hence, total APP levels can be critical for the potency of NSAIDs. Besides their higher sensitivity for APP modulation, primary neurons are also more prone to cell toxicity mediated by NSAIDs and give, in addition to APP processing, valuable information on the neurotoxicity of substances.

Further, we analyzed the calpain inhibitor calpeptin in our culture models. Interestingly, we replicated the $A \beta 42$ increasing effect of calpeptin in primary cultures but not in the $\mathrm{H} 4$ cell line although the modulating activity of calpeptin was initially demonstrated in a murine fibroblast-like cell line and in murine and human neuroblastoma cells (Mathews et al. 2002). Hence, the lack of effect of calpeptin in $\mathrm{H} 4$ cells can be attributed at least in parts to the nature of the $\mathrm{H} 4$ neuroglioma cell line. This finding highlights the problem that most data on APP processing has been generated in a variety of different cell lines and hence a comparison between cellular assays proves difficult. Some cell lines originate from non- 
neuronal cell types, whereas others are from different species. Also, the expression of various FAD-linked mutations in cell lines does not allow a comprehensive comparison of secretase inhibitors and modulators. Therefore, the use of a unifying cell culture system such as primary neurons would be of advantage to allow a direct comparison of APP modifying substances.

In conclusion, primary telencephalic chicken neurons are a well-suited cell culture model for testing drugs targeting $A \beta$ formation. Primary chicken neurons produce endogenous levels of wildtype APP and PS1 and secrete A $\beta$ peptides which are identical in their sequence to human $A \beta$ and thus reflect the molecular condition of sporadic Alzheimer's disease. In addition, primary telencephalic neurons are overall more sensitive to pharmacological intervention than immortalized cell lines with the exception of $\gamma$-secretase inhibitors and in sum define the potency and mechanism of drugs more accurately regarding their in vivo efficacy and toxicity. For drug discovery, primary neurons expressing wildtype APP are a suitable system to model sporadic Alzheimer's disease. In contrast, cell lines producing proteins containing FAD-linked mutations exhibit a model for testing drugs targeting familial forms of AD.

Open Access This article is distributed under the terms of the Creative Commons Attribution Noncommercial License which permits any noncommercial use, distribution, and reproduction in any medium, provided the original author(s) and source are credited.

\section{References}

Carrodeguas JA, Rodolosse A, Garza MV et al (2005) The chick embryo appears as a natural model for research in beta-amyloid precursor protein processing. Neuroscience 134:1285-1300

Citron M, Oltersdorf T, Haass C et al (1992) Mutation of the betaamyloid precursor protein in familial Alzheimer's disease increases beta-protein production. Nature 360:672-674

Citron M, Teplow DB, Selkoe DJ (1995) Generation of amyloid beta protein from its precursor is sequence specific. Neuron 14:661670

Cole SL, Vassar R (2008) The role of amyloid precursor protein processing by BACE1, the beta-secretase, in Alzheimer disease pathophysiology. J Biol Chem 283:29621-29625

Czirr E, Leuchtenberger S, Dorner-Ciossek C et al (2007) Insensitivity to Abeta42-lowering nonsteroidal antiinflammatory drugs and gamma-secretase inhibitors is common among aggressive presenilin-1 mutations. J Biol Chem 282:24504-24513

Dahlgren KN, Manelli AM, Stine WB et al (2002) Oligomeric and fibrillar species of amyloid-beta peptides differentially affect neuronal viability. J Biol Chem 277:32046-32053

De Strooper B (2007) Loss-of-function presenilin mutations in Alzheimer disease. Talking point on the role of presenilin mutations in Alzheimer disease. EMBO Rep 8:141-146

Dovey HF, John V, Anderson JP et al (2001) Functional gammasecretase inhibitors reduce beta-amyloid peptide levels in brain. J Neurochem 76:173-181
Durkin JT, Murthy S, Husten EJ et al (1999) Rank-order of potencies for inhibition of the secretion of abeta40 and abeta42 suggests that both are generated by a single gamma-secretase. J Biol Chem 274:20499-20504

Esselmann H, Maler JM, Kunz N et al (2004) Lithium decreases secretion of Abeta1-42 and C-truncated species Abeta1-37/38/39/ 40 in chicken telencephalic cultures but specifically increases intracellular Abeta1-38. Neurodegener Dis 1:236-241

Gasparini L, Rusconi L, Xu H et al (2004) Modulation of betaamyloid metabolism by non-steroidal anti-inflammatory drugs in neuronal cell cultures. J Neurochem 88:337-348

Ghosh AK, Gemma S, Tang J (2008) Beta-secretase as a therapeutic target for Alzheimer's disease. Neurotherapeutics 5:399-408

Golstein P, Kroemer G (2007) Cell death by necrosis: towards a molecular definition. Trends Biochem Sci 32:37-43

Gutmann B, Hutter-Paier B, Skofitsch G et al (2002) In vitro models of brain ischemia: the peptidergic drug cerebrolysin protects cultured chick cortical neurons from cell death. Neurotox Res 4:59-65

Haass C (2004) Take five-BACE and the gamma-secretase quartet conduct Alzheimer's amyloid beta-peptide generation. Embo J 23:483-488

Haass C, Selkoe DJ (2007) Soluble protein oligomers in neurodegeneration: lessons from the Alzheimer's amyloid beta-peptide. Nat Rev Mol Cell Biol 8:101-112

Haass C, Lemere CA, Capell A et al (1995) The Swedish mutation causes early-onset Alzheimer's disease by beta-secretase cleavage within the secretory pathway. Nat Med 1:1291-1296

Hara MR, Snyder SH (2007) Cell signaling and neuronal death. Annu Rev Pharmacol Toxicol 47:117-141

Hardy J, Selkoe DJ (2002) The amyloid hypothesis of Alzheimer's disease: progress and problems on the road to therapeutics. Science 297:353-356

Harwood SM, Yaqoob MM, Allen DA (2005) Caspase and calpain function in cell death: bridging the gap between apoptosis and necrosis. Ann Clin Biochem 42:415-431

Haugabook SJ, Yager DM, Eckman EA et al (2001) High throughput screens for the identification of compounds that alter the accumulation of the Alzheimer's amyloid beta peptide (Abeta). J Neurosci Methods 108:171-179

Hussain I, Hawkins J, Harrison D et al (2007) Oral administration of a potent and selective non-peptidic BACE-1 inhibitor decreases beta-cleavage of amyloid precursor protein and amyloid-beta production in vivo. J Neurochem 100:802-809

Imbimbo BP (2008) Therapeutic potential of gamma-secretase inhibitors and modulators. Curr Top Med Chem 8:54-61

Klafki H, Abramowski D, Swoboda R et al (1996) The carboxyl termini of beta-amyloid peptides 1-40 and 1-42 are generated by distinct gamma-secretase activities. J Biol Chem 271:2865528659

Koo EH, Squazzo SL (1994) Evidence that production and release of amyloid beta-protein involves the endocytic pathway. J Biol Chem 269:17386-17389

Kukar TL, Ladd TB, Bann MA et al (2008) Substrate-targeting gamma-secretase modulators. Nature 453:925-929

Leuchtenberger S, Maler J, Czirr E et al (2009) Nonsteroidal antiinflammatory drugs and ectodomain shedding of the amyloid precursor protein. Neurodegener Dis 6:1-8

Lewczuk P, Esselmann H, Otto $M$ et al (2004) Neurochemical diagnosis of Alzheimer's dementia by CSF Abeta42, Abeta42/ Abeta40 ratio and total tau. Neurobiol Aging 25:273-281

Mathews PM, Jiang Y, Schmidt SD et al (2002) Calpain activity regulates the cell surface distribution of amyloid precursor protein. Inhibition of calpains enhances endosomal generation of beta-cleaved C-terminal APP fragments. J Biol Chem 277:36415-36424 
Mullan M (1992) Familial Alzheimer's disease: second gene locus located. Bmj 305:1108-1109

Mullan M, Houlden H, Windelspecht M et al (1992) A locus for familial early-onset Alzheimer's disease on the long arm of chromosome 14 , proximal to the alpha 1-antichymotrypsin gene. Nat Genet 2:340-342

$\mathrm{Na} \mathrm{CH}$, Jeon SH, Zhang G et al (2007) Inhibition of amyloid betapeptide production by blockage of beta-secretase cleavage site of amyloid precursor protein. J Neurochem 101:1583-1595

Netzer WJ, Dou F, Cai D et al (2003) Gleevec inhibits beta-amyloid production but not Notch cleavage. Proc Natl Acad Sci U S A 100:12444-12449

Okochi M, Fukumori A, Jiang J et al (2006) Secretion of the Notch-1 Abetalike peptide during Notch signaling. J Biol Chem 281:7890-7898

Page RM, Baumann K, Tomioka M et al (2008) Generation of Abeta38 and Abeta42 is independently and differentially affected by familial Alzheimer disease-associated presenilin mutations and gamma-secretase modulation. J Biol Chem 283:677-683

Pettmann B, Louis JC, Sensenbrenner M (1979) Morphological and biochemical maturation of neurones cultured in the absence of glial cells. Nature 281:378-380

Sarasa M, Pesini P (2009) Natural non-transgenic animal models for research in Alzheimer's disease. Curr Alzheimer Res 6:171-178

Silvestri R (2009) Boom in the development of non-peptidic betasecretase (BACE1) inhibitors for the treatment of Alzheimer's disease. Med Res Rev 29:295-338

Stachel SJ, Coburn CA, Steele TG et al (2004) Structure-based design of potent and selective cell-permeable inhibitors of human betasecretase (BACE-1). J Med Chem 47:6447-6450

Walsh DM, Selkoe DJ (2007) A beta oligomers - a decade of discovery. J Neurochem 101:1172-1184
Walsh DM, Klyubin I, Fadeeva JV et al (2002) Naturally secreted oligomers of amyloid beta protein potently inhibit hippocampal long-term potentiation in vivo. Nature 416:535-539

Weggen S, Eriksen JL, Das P et al (2001) A subset of NSAIDs lower amyloidogenic Abeta42 independently of cyclooxygenase activity. Nature 414:212-216

Weggen S, Eriksen JL, Sagi SA et al (2003) Evidence that nonsteroidal anti-inflammatory drugs decrease amyloid beta 42 production by direct modulation of gamma-secretase activity. J Biol Chem 278:31831-31837

Wolfe MS (2006) The gamma-secretase complex: membraneembedded proteolytic ensemble. Biochemistry 45:7931-7939

Wolfe MS (2008) Gamma-secretase inhibition and modulation for Alzheimer's disease. Curr Alzheimer Res 5:158-164

Xia W, Ostaszewski BL, Kimberly WT et al (2000) FAD mutations in presenilin-1 or amyloid precursor protein decrease the efficacy of a gamma-secretase inhibitor: evidence for direct involvement of PS1 in the gamma-secretase cleavage complex. Neurobiol Dis 7:673-681

Yamakawa H, Yagishita S, Futai E et al (2010) Beta-secretase inhibitor potency is decreased by aberrant beta-cleavage location of the "Swedish mutant" amyloid precursor protein. J Biol Chem 285:1634-1642

Yang LB, Lindholm K, Yan R et al (2003) Elevated beta-secretase expression and enzymatic activity detected in sporadic Alzheimer disease. Nat Med 9:3-4

Zhang L, Song L, Parker EM (1999) Calpain inhibitor I increases beta-amyloid peptide production by inhibiting the degradation of the substrate of gamma-secretase. Evidence that substrate availability limits beta-amyloid peptide production. J Biol Chem 274:8966-8972 